\title{
Gorontalo

\section{Hipertensi dan Faktor Risikonya di Puskesmas Motolohu Kabupaten Pohuwato}

\author{
Zul Adhayani Arda'), Rifa'i Ali' ${ }^{2)}$ dan Marselina Mustapa ${ }^{3)}$ \\ 1I lmu Kesehatan Masyarakat, Fakultas Kesehatan Masyarakat Universitas Gorontalo \\ email: adhayani_r@yahoo.co.id \\ 2I lmu Kesehatan Masyarakat, Fakultas Kesehatan Masyarakat Universitas Gorontalo \\ email: rifai_ali86@yahoo.co.id \\ 3I lmu Kesehatan Masyarakat, Fakultas Kesehatan Masyarakat Universitas Gorontalo \\ email: mustapamarselina3@gmail.com
}

\begin{abstract}
Based on WHO (World Health Organization) in 2011, hypertension was causing 8 billion of the world citizen pass away every year in which almost 1.5 billion of them were in south east of Asia. The purpose of study was to determine the risk factors associated with hypertension in Pohuwato District in 2017. The study was an observational analytic with case control design. The sample of study was 202 respondents which divided into 101 case group and 101 control group in the work area of Puskesmas Motolohu in Pohuwato District. The data were analyzed by using odds ratio $(O R)$ test. The study result showed that occupation (OR=2.71; 95\% CI; 1.45-5.05), gender (OR=2.55; 95\% CI; 1.35-4.79), smoking behavior $(O R=2.55 ; 95 \%$ CI; 1.35-4.79), hypertension history (OR=6.13; 95\% CI; 3.0412.36), and consumption of coffee (OR=3.20; 95\% CI; 1.64-6.25) were significant risk factors for occurance of hypertension. It is recomended to counseled as a means of disseminating information about risk factors and effect of hypertension to the public.
\end{abstract}

Keywords : Risk Factors, Hypertension

\section{PENDAHULUAN}

Hipertensi sering disebut sebagai pembunuh terselubung. Pada umumnya semua gangguan kesehatan yang timbul biasanya diikuti dengan tanda dan gejala. Namun hal ini tidak berlaku pada hipertensi. Hipertensi tidak memberikan gejala kepada penderita, namun bukan berarti tidak berbahaya (Santoso, 2010).

Menurut data WHO (World Health Organization) 2011, sekitar 1 milyar penduduk di seluruh dunia menderita hipertensi dimana dua pertiganya terdapat di negara-negara berkembang. Hipertensi menyebabkan 8 juta penduduk di seluruh dunia meninggal setiap tahunnya, hampir 1,5 juta penduduk diantaranya terdapat di kawasan Asia tenggara (WHO, 2011).

Hipertensi merupakan pemicu beragam penyakit seperti stroke, diabetes, dan gagal ginjal. Terlalu banyak mengkonsumsi garam, kegemukan, sembelit, merokok, alkohol, stress berkelanjutan dan diabetes dapat menjadi pemicu terjadinya hipertensi (Irianto, 2014).

Berdasarkan hasil Riset Kesehatan Dasar (Riskesdas), penyakit hipertensi di Provinsi Gorontalo tahun 2007 presentase kasusnya sebesar 7,6\% sedangkan 
Arda, dkk

pada tahun 2013 presentase kasusnya meningkat menjadi 12,1\% (Kemenkes RI, 2013). Menurut data Dinas Kesehatan Kabupaten Pohuwato tahun 2016 dilaporkan kejadian hipertensi sebanyak 1199 kasus. Jumlah kasus hipertensi yang tertinggi terjadi pada bulan Oktober sebanyak 166 kasus dan yang terendah pada bulan April yaitu 36 kasus (Dinkes Kabupaten Pohuwato, 2016).

Menurut data yang diperoleh dari Puskesmas Motolohu, prevalensi penyakit Hipertensi pada tahun 2015 sebesar 3,06\% dengan jumlah kasus sebanyak 553 kasus dimana tertinggi pada bulan Januari (84 kasus) dan terendah pada bulan Juli (35 kasus). Sedangkan tahun 2016, prevalensi penyakit Hipertensi sebesar $2,77 \%$ dengan jumlah kasus sebanyak 500 kasus dimana yang tertinggi pada bulan Maret - April (68 kasus) dan terendah pada bulan Mei (33 kasus) (Puskesmas Motolohu, 2016). Tujuan dari penelitian ini untuk menganalisis faktor risiko kejadian Hipertensi di Puskesmas Motolohu Kabupaten Pohuwato tahun 2017.

\section{METODE PENELITIAN}

Penelitian ini menggunakan penelitian observasional analitik dengan rancangan case control study. Populasi pada penelitian ini adalah semua penderita penyakit degenaratif di wilayah kerja Puskesmas Motolohu. Sampel penelitian sebanyak 202 responden yang dibagi menjadi kelompok kasus dan kontrol. Sampel kasus adalah responden yang menderita hipertensi sebanyak 101 orang. Sedangkan sampel kontrol adalah responden yang tidak menderita hipertensi sebanyak 101 orang. Teknik pengambilan sampel yang digunakan yaitu teknik purposive sampling, dimana sampel dipilih berdasarkan pertimbangan tertentu yang dibuat oleh peneliti (Notoatmodjo, 2005).

Variabel dependen dalam penelitian ini adalah kejadian hipertensi. Variabel independen adalah pekerjaan, jenis kelamin, perilaku merokok, riwayat hipertensi dan konsumsi kopi. Data dikumpulkan dari catatan rekam medik dan hasil wawancara. Data kemudian dianalisis secara univariat dan bivariat. Analisis univariat, digunakan untuk mengetahui distribusi frekuensi dari masing-masing variabel yang diteliti. Analisis bivariat, digunakan untuk mengetahui besar risiko variabel independen terhadap variabel dependen dengan menggunakan uji OR (Odds Ratio).

\section{HASIL DAN PEMBAHASAN}

\subsection{Analisis Karakteristik Responden}

Tabel 1. Distribusi Karakteristik Responden

\begin{tabular}{lcc}
\hline Karakteristik Responden & $\mathrm{n}$ & $\%$ \\
\hline Umur Responden (tahun) & & \\
$<30$ & 9 & 4,5 \\
$31-35$ & 30 & 14,9 \\
$36-40$ & 27 & 13,4 \\
$40-45$ & 18 & 8,9 \\
$45-50$ & 19 & 9,4 \\
$>50$ & 99 & 49,0 \\
Tingkat Pendidikan & & \\
SD & 110 & 54,5 \\
SMP & 44 & 21,8 \\
SMA & 42 & 20,8 \\
S1 & 6 & 3,0 \\
\hline
\end{tabular}


Hasil penelitian menunjukkan bahwa responden paling banyak berumur $>50$ tahun yaitu 99 responden (49\%). Dan jika dilihat dari variabel tingkat pendidikan, paling banyak responden hanya tamat Sekolah Dasar (SD) yaitu sebanyak 110 responden (54,5\%).

\subsection{Analisis Faktor Risiko}

Tabel 2. Faktor Risiko Kejadian Hipertensi Di Wilayah Kerja Puskesmas Motolohu Kabupaten Pohuwato Tahun 2015 - 2016

\begin{tabular}{|c|c|c|c|c|}
\hline \multirow{2}{*}{ Variabel Independen } & \multicolumn{2}{|c|}{ Kejadian Hipertensi } & \multirow{2}{*}{ Total } & \multirow{2}{*}{$\begin{array}{c}\text { OR 95\% CI } \\
\text { (LL - UL) }\end{array}$} \\
\hline & Kasus & Kontrol & & \\
\hline \multicolumn{5}{|l|}{ Pekerjaan } \\
\hline Risiko tinggi & 80 (79.2\%) & 59 (58.4\%) & 139 (68.8\%) & \multirow[t]{2}{*}{$2.71(1.4-5.0)$} \\
\hline Risiko rendah & 21 (20.8\%) & $42(41.6 \%)$ & $63(31.2 \%)$ & \\
\hline \multicolumn{5}{|l|}{ Jenis Kelamin } \\
\hline Risiko tinggi & 81 (80.2\%) & $62(61.4 \%)$ & $143(70.8 \%)$ & \multirow{2}{*}{$2.54(1.4-4.8)$} \\
\hline Risiko rendah & 20 (19.8\%) & $39(38.6 \%)$ & $59(29.2 \%)$ & \\
\hline \multicolumn{5}{|l|}{ Perilaku Merokok } \\
\hline Risiko tinggi & $81(80.2 \%)$ & $62(61.4 \%)$ & $143(70.8 \%)$ & \multirow[t]{2}{*}{$2.54(1.4-4.8)$} \\
\hline Risiko rendah & 20 (19.8\%) & 39 (38.6\%) & 59 (29.2\%) & \\
\hline \multicolumn{5}{|l|}{ Riwayat } \\
\hline Hipertensi & $88(87.1 \%)$ & $53(24.9 \%)$ & $141(69.8 \%)$ & \multirow{3}{*}{$6.13(3.0-12.4)$} \\
\hline Risiko tinggi & 13 (12,9\%) & $48(75.1 \%)$ & $61(30.2 \%)$ & \\
\hline Risiko rendah & & & & \\
\hline \multicolumn{5}{|l|}{ Konsumsi Kopi } \\
\hline Risiko tinggi & 85 (84.2\%) & $63(62.4 \%)$ & 148 (73.3\%) & \multirow[t]{2}{*}{$3.20(1.6-6.3)$} \\
\hline Risiko rendah & 16 (15.8\%) & $38(37.6 \%)$ & $54(26.7 \%)$ & \\
\hline
\end{tabular}

Hasil analisis bivariat dengan uji Odss Ratio menunjukkan bahwa status pekerjaan $(\mathrm{OR}=2.71 ; 95 \% \mathrm{CI} ; 1.45-5.05)$, jenis kelamin $(\mathrm{OR}=2.54$; 95\% CI; 1.35 4.79), perilaku merokok $(\mathrm{OR}=2.54 ; 95 \% \mathrm{CI} ; 1.35-4.79)$, riwayat hipertensi $(\mathrm{OR}=6.13$; 95\% CI; 3.04-12.36), dan konsumsi kopi (OR=3.20; 95\% CI; 1.64 6.25) merupakan faktor risiko yang signifikan terhadap kejadian Hipertensi.

Pekerjaan dalam arti luas adalah aktivitas utama yang dilakukan oleh manusia. Dalam arti sempit, istilah pekerjaan digunakan untuk suatu tugas atau kerja yang menghasilkan uang bagi seseorang. Dalam pembicaraan sehari - hari istilah ini sering dianggap sinonim dengan profesi. Orang yang bekerja umunya telah melakukan beberapa aktivitas fisik yang mengeluarkan tenaga selama di tempat kerja. Kurangnya aktivitas akan menjadi salah satu faktor risiko terjadinya suatu penyakit, terutama peyakit degeneratif seperti hipertensi (Nadesul, 2014).

Menurut hasil penelitian ini responden yang tidak bekerja (risiko tinggi) sebanyak 139 responden $(68.8 \%), 80$ responden diantaranya menderita Hipertensi. Hasil uji statistik dengan odds rasio menunjukkan bahwa pekerjaan merupakan faktor risiko yang signifikan terhadap terjadinya Hipertensi dengan nilai $\mathrm{OR}=2.71$. Artinya, responden yang tidak bekerja berisiko 2.71 kali lebih besar untuk menderita hipertensi dibandingkan responden yang bekerja.

Hasil penelitian ini tidak sejalan dengan penelitian yang dilakukan oleh Abdul Farid tidak ada hubungannya dengan kejadian hipertensi pada nelayan 
Arda, dkk

dengan hasil analisis yang di dapat nilai OR sebesar 1.163 dengan 95\% $C 1=$ 0.679 - 1.993 (Farid, 2010).

Jenis kelamin adalah perbedaan bentuk, sifat, dan fungsi biologi laki - laki dan perempuan yang menentukan perbedaan peran mereka dalam menyelenggarakan upaya meneruskan garis keturunan. Perbedaan ini terjadi karena mereka memiliki alat reproduksi untuk meneruskan keturunan yang berbeda. Alat reproduksi laki-laki dan perempuan hanya dapat berfungsi kalau dipadukan (Sholihah, 2006). Laki-laki dan perempuan mempunyai risiko yang berbeda terhadap kejadian penyakit hipertensi. Laki-laki lebih berisiko dibanding perempuan. Namun, pada usia tertentu keduanya mempunyai besar risiko yang hampir sama seperti saat berumur 45-64 tahun, bahkan perempuan dapat menjadi lebih berisiko (Tilong, 2014).

Hasil penelitian ini menunjukkan bahwa responden yang berjenis kelamin laki-laki (risiko tinggi) sebanyak 143 responden (70.8\%), dimana 81 responden diantaranya menderita hipertensi. Hasil uji statistik dengan odds rasio menunjukkan bahwa jenis kelamin merupakan faktor risiko yang signifikan terhadap terjadinya Hipertensi dengan nilai $\mathrm{OR}=2.54$. Artinya, responden yang berjenis kelamin lai-laki berisiko 2.54 kali lebih besar untuk menderita hipertensi dibandingkan responden yang berjenis kelamin perempuan.

Penelitian ini sejalan dengan hasil penelitian yang dilakukan oleh Agnesia Nuarima Kartikasari yang memperoleh hasil bahwa pekerjaan merupakan faktor risiko terjadinya hipertensi $(O R=3.05)$ (Kartikasari, 2012). Tetapi tidak sejalan dengan penelitian yang dilakukan oleh Aris Sugiharto, yang menyatakan bahwa jenis kelaminbukan merupakan faktor risiko terjadinya hipertensi(OR=0.79) (Sugiharto, 2007).

Merokok merupakan salah satu kebiasaan yang lazim ditemui dalam kehidupan sehari-hari. Sangat mudah untuk menemukan orang yang merokok, lelaki-wanita, tua-muda, kaya miskin tanpa terkecuali. Walaupun dari segi kesehatan, tidak ada satupun manfaat yang diperoleh dengan merokok (Bustan, 2007). Menurut para ahli kesehatan, rokok sangat banyak mengandung nikotin yang dapat mengakibatkan terjadinya peningkatan denyut jantung, meningkatkan tekanan darah,menurunkan kadar kolestrol HDL, meningkatkan kadar kolestrol LDL, dan mempercepat atreriosklerosis (Tilong, 2014).

Menurut penelitian ini, responden yang merokok (risiko tinggi) sebanyak 143 responden $(70.8 \%)$, dimana 81 responden diantaranya menderita hiertensi. Hasil uji statistik dengan odds rasio menunjukkan bahwa perilaku merokok merupakan faktor risiko yang signifikan terhadap terjadinya Hipertensi dengan nilai $\mathrm{OR}=2.54$. Artinya, responden yang merokok berisiko 2.54 kali lebih besar untuk menderita hipertensi dibandingkan responden yang tidak merokok.

Hasil penelitian ini sejalan dengan hasil penelitian yang diperoleh Fani Oktavia yang menyatakan bahwa kebiasaan merokok merupakan faktor risiko yang bermakana terhadap kejadian hipertensi (OR=2.61; 95\% CI;1.00 - 6.93) (Oktavia, 2016). Namun, idak sejalan dengan hasil penelitian yang dilakukan oleh Sutangi yang menunjukkan bahwa merokok bukan merupakan faktor 
risiko terjadinya hipertensi pada masyarakat di desa Sruni $(\mathrm{OR}=0.748)$ (Sutangi dan Winantri, 2010).

Genetika merupakan salah satu faktor yang memiliki andil yang cukup besar dalam terjadinya hipertensi. Bahkan suatu hasil penelitian menyatakan bahwa 9 dari 10 orang yang menderita hipertensi terbukti karena faktor keturunan. Tetapi, faktor genetik ini tidak akan memberikan pengaruh apapun jika tidak didukung oleh situasi dan lingkungan yang ada. Dalam arti bahwa faktor genetik dapat menjadi ancaman jika didukung oleh berbagai faktor lain yang ada pada penderita, seperti gaya hidup, tingkat stres, pola makan terutama dalam hal konsumsi garam serta kurangnya aktivitas fisik (Tilong, 2014).

Hasil penelitian ini menunjukkan bahwa responden yang memiliki riwayat hipertensi (risiko tinggi) sebanyak 141 responden (69.8\%), dimana 88 responden diantaranya menderita hipertensi. Hasil uji statistik dengan odds rasio menunjukkan bahwa riwayat hipertensi merupakan faktor risiko yang signifikan terhadap terjadinya hipertensi dengan nilai $\mathrm{OR}=6.13$. Artinya, responden yang memiliki riwayat hipertensi berisiko 6.13 kali lebih besar untuk menderita hipertensi dibandingkan responden yang tidak memiliki riwayat hipertensi.

Penelitian ini didukung oleh penelitian yang dilakukan Elvyrah Faisal, dimana diperoleh bahwa riwayat hipertensi merupakan faktro risiko terjadinya hipertensi $(\mathrm{OR}=2)$, yang berarti riwayat hipertensi berisiko 2 kali lebih besar menderita hipertensi dibanding mereka yang tidak mempunyai riwayat hipertensi (Faisal et al., 2011).

Kopi mengandung senyawa yang disebut kafein yang mengakibatkan orang terjaga, sulit mengendalikan emosi, menyebabkan kecanduan hingga menjadi salah satu pemicu kanker. Hal ini dapat terjadi jika seseorang mengkonsumsi kopi lebih dari $250 \mathrm{mg}$ sekaligus atau setara dengan 3 cangkir kopi. Selain itu, kopi juga meningkatkan aliran darah dalam ginjal sehingga produksi urine bertambah. Bahkan para ahli memberikan peringatan bagi seseorang yang mengidap penyakit atau gejala serangan jantung, gangguan ginjal, dan tekanan darah tinggi untuk mengkonsumsi kopi tak lebih dari secangkir perhari. Kopi untuk kesehatan menurut para peneliti jika dikonsumsi dalam jumlah yang tidak berlebihan (tidak lebih dari 2 gelas perhari) (Ngabidin, 2013).

Hasil penelitian ini menunjukkan bahwa responden yang mengkonsumsi kopi $>2$ cangkir per hari (risiko tinggi) sebanyak 148 responden $(73.3 \%$ ), dimana 85 responden diantaranya menderita hipertensi. Hasil uji statistik dengan odds rasio menunjukkan bahwa konsumsi kopi merupakan faktor risiko yang signifikan terhadap terjadinya hipertensi dengan nilai $\mathrm{OR}=3.20$. Artinya, responden yang mengkonsumsi kopi $>2$ cangkir perhari berisik 
Arda, dkk

3.20 kali lebih besar untuk menderita hipertensi dibandingkan responden yang mengkonsumsi kopi $\leq 2$ cangkir perhari.

Penelitian ini sejalan dengan penelitian yang dilakukan oleh Elvivin pada nelayan Suku Bajo di Pulau Tasipi Kabupate Muna Barat tahun 2015 yang menunjukkan bahwa kebiasaan minum kopi merupakan faktor risiko yang bermakana terhadap kejadian hipertensi $(\mathrm{OR}=12.5)$ (Elvivin et al., 2015).

\section{KESIMPULAN DAN SARAN}

Status pekerjaan, jenis kelamin, perilaku merokok, riwayat hipertensi dan konsumsi kopi merupakan faktor risiko yang signifikan terhadap kejadian hipertensi di wilayah kerja Puskesmas Motolohu Kabupaten Pohuwato. Untuk itu disarankan agar dapat dilakukan penyuluhan sebagai sarana penyebaran informasi tentang faktor risiko dan bahaya hipertensi secara luas pada masyarakat.

\section{REFERENSI}

Bustan, MN. 2007. Epidemiologi Penyakit Tidak Menular. Rineka Cipta. Jakarta.

Dinas Kesehatan Kabupaten Pohuwato. 2016. Data Penyakit Tidak Menular tahun 2015-2016. Kabupaten Pohuwato.

Elvivin, Lestari H, dan Ibrahim K. 2015. Analisis Faktor Risiko Kebiasaan Mengkonsumsi Garam, Alkohol, Kebiasaan Merokok, Dan Minum Kopi Terhadap Kejadian Hipertensi Pada Nelayan Suku Bajo Di Pulau Tasipi Kabupaten Muna Barat Tahun 2015. Jurnal. Fakultas Kesehatan Masyarakat Universitas Halu Oleo. Kendari. https://media.neliti.com/media/publications /185583-ID-analisis-faktorrisiko-kebiasaan-mengkon.pdf. Diakses tanggal 9 Juni 2017.

Faisal, E, Djarwoto B, dan Murtiningsih B. 2011. Faktor Risiko Hipertensi pada Wanita Pekerja Dengan Peran Ganda Kabupaten Bantul. https://journal.ugm.ac.id/bkm/article/view/3388. Diakses tanggal 9 Juni 2017.

Farid, A. 2010. Faktor-faktor Risiko Hipertensi Sistolik Terisolasi pada Lanjut Usia. Skripsi. Politeknik Kesehatan Palu. Palu.

Irianto, K. 2014. Epidemiologi Penyakit Menular dan Tidak Menular, Panduan Klinis. Alfabeta. Bandung.

Kartikasari, AN. 2012. Faktor Risiko Hipertensi Pada Masyarakat Di Desa Kabongan Kidul, Kabupaten Rembang. Karya Tulis Ilmiah. Fakultas Kedokteran Universitas Diponegoro. Semarang.

Kemenkes RI. 2013. Riset Kesehatan Dasar (RISKESDAS) 2013. Badan Penelitian dan Pengembangan Kesehatan, Kementerian Kesehatan Republik Indonesia. Jakarta.

http://www.depkes.go.id/resources/download/general/Hasil\%20Riskesda s\%202013.pdf. Diakses tanggal 28 Januari 2017.

Nadesul, H. 2014. Mencegah Serangan Jantung Stroke Gagal Ginjal. PT Kompas Media Nusantara. Jakarta. 
Ngabidin. 2013. Manfaat dan Efek Bahaya Minum Kopi. http://www.ngabidin.web.id/2013/02/manfaat-dan-efek-sampingminum-kopi.html. Diakses tanggal 25 Januari 2017.

Notoatmodjo, S. 2005. Metodologi Penelitian Kesehatan. Rineka Cipta. Jakarta.

Oktavia, F. 2016. Besar Risiko Kejadian Hipertensi Berdasarkan Faktor Demografi, Biologi, dan Perilaku pada Tentara Nasional Indonesia (TNI). Skripsi. Fakultas Kesehatan Masyarakat Universitas Airlangga. Surabaya.

Puskesmas Motolohu. 2016. Data Penyakit Hipertensi 2015-2016. Kabupaten Pohuwato.

Santoso, D. 2010. Membonsai Hipertensi. Penerbit Jaring Pena. Surabaya.

Sholihah, N. 2006. Gender dan Jenis Kelamin. https:// pmiiliga.wordpress.com/2006/10/09/nikmatus-sholihah-genderdan-jenis-kelamin. Diakses tanggal 17 Februari 2017.

Sugiharto, A. 2007. Faktor-faktor Risiko Hipertensi Grade II Pada Masyarakat (Studi Kasus di Kabupaten Karang Anyar). Tesis. Program Pasca Sarjana Universitas Diponegoro. Semarang.

Sutangi, H dan Winantri. 2010. Faktor Yang Berhubungan Dengan Kejadian Hipertensi Pada Wanita Lansia Di Posbidu Desa Suka Urip Kecamatan BalonganIndramayu. http://ejournal.unwir.ac.id/jurnal.php?detail=jurnal \&file=H_sutangi_no_10.pdf\&id=578\&cd=0b2173ff6ad6a6fb09c95f6d5000 1 df6\&name=H_sutangi_no_10.pdf. Diakses tanggal 9 Juni 2017.

Tilong, AD. 2014. Waspada Penyakit-penyakit Mematikan Tanpa Gejala Menyolok. Buku Biru. Jogjakarta.

World Health Organization (WHO). 2011. Hypertension Fact Sheet. WHO: Department of Sutainable Development and Healthy Environments. www.searo.who.int. Diakses tanggal 28 Januari 2017. 